Received: 15-10-2018. Accepted: 28-12-2018. Published: 31-12-2018

\title{
Testing Effect Mediation of Regional Expenditure on Gross Regional Domestic Products \\ Muhamad Armawaddin ${ }^{1}$, Syamsir Nur ${ }^{2}$
}

\author{
University of Halu Oleo, Kendari, Indonesia ${ }^{12}$
}

\begin{abstract}
This study aims to analyses and determine the dominant factors that influence regional spending and its impact on gross regional domestic products and to analyses the direct and indirect effects of regional own revenue, general allocation fund and revenue sharing fund on gross regional domestic products mediated by regional expenditure. Data uses panel data with 17 Regency / Municipality in Southeast Sulawesi and observation period for 2015-2017. Data analysis used path analysis with AMOS 18.0 program and indirect effect test using the Sobel test. The results of the study conclude: a) General Allocation Funds and Revenue Sharing Funds significantly affect Regional Expenditures, while Regional Own Revenues are insignificant; b) Regional Own Revenue and Revenue Sharing Fund significantly affect the Gross Regional Domestic Product, while the General Allocation Fund is not significant; c) Regional Expenditure significantly mediated the effect of General Allocation Funds and Revenue Sharing Fund on Gross Regional Domestic Products, while Regional Expenditures do not significantly mediate in the influence of Regional Own Revenue on Gross Regional Domestic Product. Whereas to increase the gross regional domestic products in Regency / Municipality in Southeast Sulawesi, it is better to regulate Regional Expenditure allocations sourced from the General Allocation Fund.
\end{abstract}

Keywords: Regional expenditure; gross regional domestic products

\section{Introduction}

Economic growth is a requirement that is needed in carrying out economic development. Growth is also a major measure of development success. Economic growth measures the achievement of the development of an economy from one period to the next. The ability of a country to produce goods and services will increase due to factors of production that always experience an increase in the number and quality. In macro analysis, the level of economic growth achieved by a country is measured by the development of real national income achieved by a country or region. Regional development is an integral part of national development carried out in improving community welfare. The progress of sustainable economic growth in each region is of concern to the government because basically national economic growth is an aggregation of regional economic growth. Economic growth between regions in Indonesia is very diverse.

This diversity is one of the factors that led to the conception of developed and underdeveloped regions. According to Keynes, the economic growth of a country or region is determined by the amount of consumption, government, net investment and exports. The focus in this paper is the extent to which government expenditure factors can predict changes in economic growth in regency / municipality in Southeast Sulawesi. Government expenditure is measured by the value of regency / municipality expenditure from year to year. Then regional expenditure is predicted by local own revenue, general allocation funds and revenue sharing fund.

This study refers to (Herlina, 2013) research that analyses the factors that influence Regional Expenditure and its effect on Gross Regional Domestic Products. This study analysed the direct and indirect effects of Regional Own Revenue, General Allocation Fund and Revenue Sharing Fund to Gross Regional Domestic Products using regression analysis. Regression analysis is a statistical tool that analyses the relationship / direct influence of one or several independent variables on one dependent variable so that to find out the indirect effect must be done separately and manually. Therefore, by using the same variables as (Herlina, 2013) research, this study re-examined the direct and indirect effects of Regional Own Revenue, General Allocation Fund and Revenue Sharing Fund on Gross Regional Domestic Products simultaneously using path analysis with AMOS 18.0 software with different objects and observation periods. In addition, the research will examine the mediating role of Regional Expenditure variables on the influence of Regional Own Revenue, General Allocation Fund and Revenue Sharing Fund to Gross Regional Domestic Products. And also will determine the dominant factor that affects Regional Expenditure

\footnotetext{
1 adiox68@gmail.com

2 syamsirnur81@gmail.com
} 
in predicting Gross Regional Domestic Products.

The results of research (Nasution, 2009); (Rarung, 2016); (Setiyawati, 2007); (Uhise, 2012); found Regional Own Revenue, General Allocation Fund and Revenue Sharing Fund have significant influence on Gross Regional Domestic Products. The results of research (Armawaddin, 2015); (Armawaddin, Rumbia, \& Afiat, 2018); (Afrizawati, 2015); (Devita, Delis, \& Junaidi, 2014); (Ernayani, 2017); (Sari \& Asyik, 2017); (Putra \& Dwirandra, 2015); (Solikin, 2016); (Inayati \& Setiawan, 2017); (Masayu Rahma Wati, 2017); (Murniasih \& Mulyadi, 2011); (Nurdini, Wiratno, \& Farida, 2015) found Regional Own Revenue, General Allocation Fund and Revenue Sharing Fund have significant influence on Regional Expenditure. The results of research (Deviani, 2016); (Deswantoro, 2017) found Regional Expenditure have significant influence on Gross Regional Domestic Products.

Different results are expressed by research (Herlina, 2013); (Tahar \& Zakhiya, 2011) found Regional Own Revenue, General Allocation Fund and Revenue Sharing Fund have not significant influence on Regional Expenditure and Gross Regional Domestic Products. The other results (Herlina, 2013) Regional Expenditure have not significant influence on Gross Regional Domestic Products.

Based on the reconstruction models of research (Herlina, 2013) and differences in the results of previous studies, this study purpose: (1) to analyze and determine the dominant factors that influence Regional Expenditure and its impact on Gross Regional Domestic Products. (2) analyzing the direct and indirect effects of regional own revenue, general allocation of funds and revenue sharing fund on Gross Regional Domestic Products mediated with Regional Expenditure. Data uses a panel data with 17 regencies/ municipalities in Southeast Sulawesi and observation period for 2015-2017.

\section{Literature Review}

The difference between the results of previous studies became the basis for this research. This research model uses three independent variables (Regional Own Revenue, General Allocation Funds, and Revenue Sharing Funds), one mediating variable (Regional Expenditures) and one dependent variable Gross Regional Domestic Product). The relationship between variables of Regional Original Revenue, General Allocation Funds, and Revenue Sharing Funds with Regional Expenditures is formulated based on the results of the research (Armawaddin, 2015); (Armawaddin, Rumbia, \& Afiat, 2018); (Afrizawati, 2015); (Devita, Delis, \& Junaidi, 2014); (Ernayani, 2017); (Sari \& Asyik, 2017); (Putra \& Dwirandra, 2015); (Solikin, 2016); (Inayati \& Setiawan, 2017); (Masayu Rahma Wati, 2017); (Murniasih \& Mulyadi, 2011); (Nurdini, Wiratno, \& Farida, 2015) found Regional Own Revenue, General Allocation Fund and Revenue Sharing Fund have significant influence on Regional Expenditure. The contradiction is research (Herlina, 2013); (Tahar \& Zakhiya, 2011) found Regional Own Revenue, General Allocation Fund and Revenue Sharing Fund have not significant influence on Regional Expenditure.

The relationship between variables of Regional Original Revenue, General Allocation Funds, and Revenue Sharing Funds with Gross Regional Domestic Product is formulated based on the results of the study (Nasution, 2009); (Rarung, 2016); (Setiyawati, 2007); (Uhise, 2012); found Regional Own Revenue, General Allocation Fund and Revenue Sharing Fund have significant influence on Gross Regional Domestic Products. The contradiction is research (Herlina, 2013); (Tahar \& Zakhiya, 2011) found Regional Own Revenue, General Allocation Fund and Revenue Sharing Fund have not significant influence on Gross Regional Domestic Products. The relationship between variable Regional Expenditures and Gross Regional Domestic Product is formulated based on the results of the study (Deviani, 2016); (Deswantoro, 2017) found Regional Expenditure have significant influence on Gross Regional Domestic Products. The contradiction is research (Herlina, 2013) Regional Expenditure have not significant influence on Gross Regional Domestic Products.

In this study will be tested the significance of the mediating effect of Regional Original Revenue in the influence of Regional Own Revenue, General Allocation Funds, and Revenue Sharing Funds with the Gross Regional Domestic Product using the Sobel test. The significance testing of mediation influence is done partially considering the limitations of literature. The conceptual framework of this research is seen in Picture 1. 


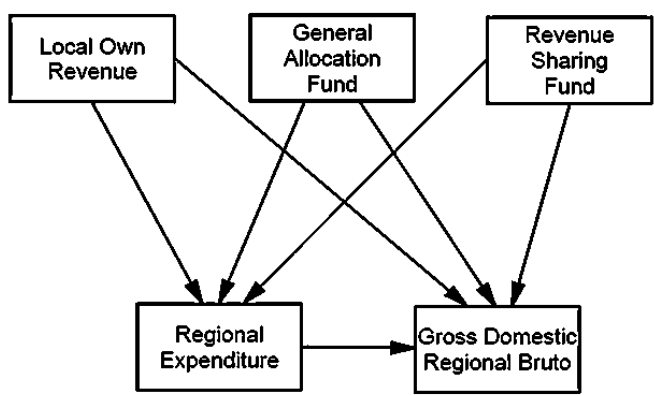

Picture 1. Conceptual framework of research follows:

Based on conceptual framework of research, hence can be proposed research hypothesis as

H1: Regional Own Revenue, General Allocation Fund and Revenue Sharing Fund Has Significant Influence on Regional Expenditure

H2: Regional Own Revenue, General Allocation Fund and Revenue Sharing Fund Has Significant Influence on Gross Domestic Regional Products.

H3: Regional Expenditure Has Significant Influence on Gross Domestic Regional Products.

H4: Regional Own Revenue, General Allocation Fund and Revenue Sharing Fund Has Significant Influence on Gross Domestic Regional Products mediating Regional Expenditure.

\section{Methodology}

This research includes the type of research that analyzes the relationship / influence of independent variables on the dependent variable. The independent variable is Regional Own Revenue, General Allocation Fund and Revenue Sharing Fund. While the dependent variable is Regional Expenditure and Gross Domestic Regional Products. Data uses panel data with 17 regency / municipality in Southeast Sulawesi and observation period for 2015-2017. Data analysis used path analysis with AMOS 18.0 program and indirect effect test (mediation role) using the Sobel test. Hypothesis testing using $\mathrm{t}$ test and $\mathrm{F}$ test by comparing $\mathrm{p}$-value with $\alpha(5 \%)$. The acceptance criteria for the hypothesis proposed if $\mathrm{p}$-value $\mathrm{t}$-statistics / F-statistics $\leq$ value $\alpha(5 \%)$. The analysis strategy is explained as follows:

Determine the dominant factors that influence Regional Expenditure using regression analysis with AMOS 18.0 program.

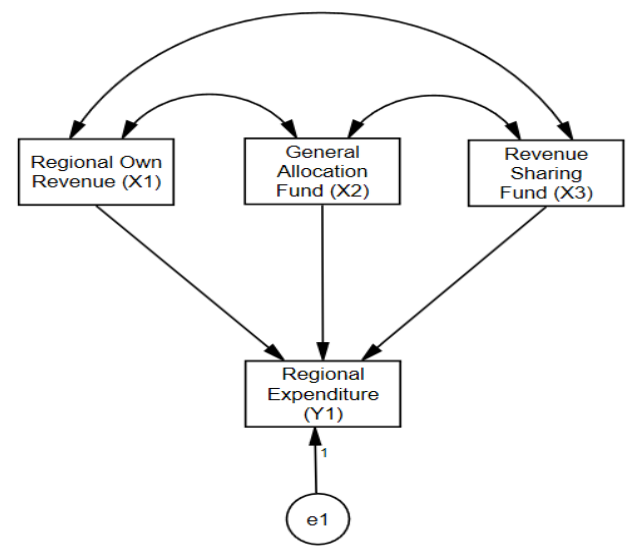

Picture 2. Determine the dominant factors that influence regional expenditure

Based on Picture 2, describing the relationship between independent variables with the dependent variable stated in the regression equation is:

$Y_{1}=\beta_{0}+\beta_{1} X_{1}+\beta_{2} X_{2}+\beta_{3} X_{3}+e_{1}$

Notes.

$\mathrm{Y}_{1} \quad$ : Dependent variable 1 (regional expenditure)

$\beta_{0} \quad$ : Intercept 
$\beta_{1}, \beta_{2}, \beta_{3} \quad$ : Regression of coefficient

$\mathrm{X}_{1}, \mathrm{X}_{2}, \mathrm{X}_{3}$ : Independent variable (regional own revenue, general allocation fund and revenue sharing fund)

$\mathrm{e}_{1} \quad$ : Error term 1

To determine which dominant factors affect Regional Expenditure is done by observing the highest t statistic value from the influence of Regional Own Revenue, General Allocation Fund and Revenue Sharing Fund on Regional Expenditure.

Determine the direct effects of Regional Own Revenue, General Allocation Fund and Revenue Sharing Fund on Regional Expenditure and Gross Regional Domestic Products using path analysis with AMOS 18.0 program.

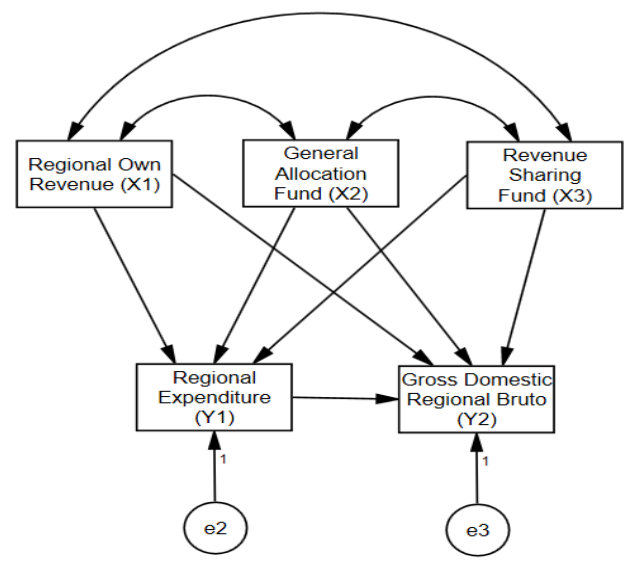

Picture 3. Determine the direct and indirect effects of Regional Own Revenue, General Allocation Fund and Revenue Sharing Fund on Gross Regional Domestic Products mediated by Regional Expenditure

Based on picture 3, the relationship between variables in the model can be stated in the equation of the path as follows:

$Y_{1}=\beta_{0}+\beta_{1} X_{1}+\beta_{2} X_{2}+\beta_{3} X_{3}+e_{2}$

$Y_{2}=\beta_{01}+\beta_{4} Y_{1}+e_{3}$

Notes.

$\mathrm{Y}_{2}$ : Dependent variable 2 (Gross Regional Domestic Products)

Determine mediating effects of Regional Expenditure In Influence Regional Own Revenue, General Allocation Fund and Revenue Sharing Fund on Gross Regional Domestic Products.

The indirect effect of mediation test is the development of the test conducted by (Sobel, 2013) and (Baron \& Kenny, 1986). The test steps of indirect influence / influence of mediation are:

Determine direct effect of Regional Own Revenue, General Allocation Fund and Revenue Sharing Fund on Regional Expenditure.

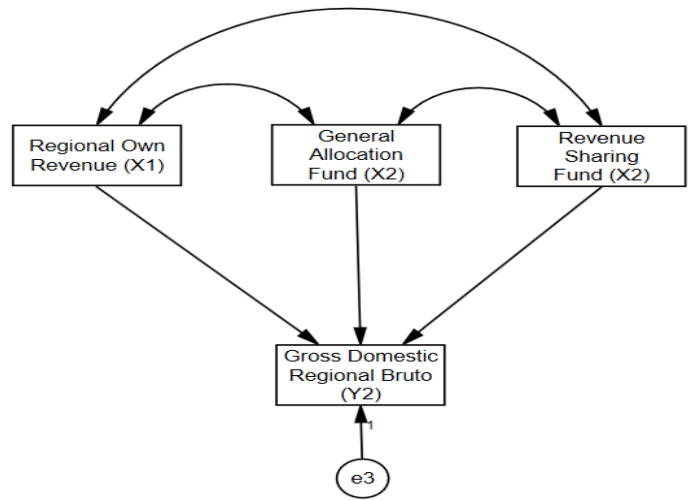

Picture 4. The direct effect of Regional Own Revenue, General Allocation Fund and Revenue Sharing Fund on Regional Expenditure 
Determine direct effect of Regional Expenditure on Gross Regional Domestic Products

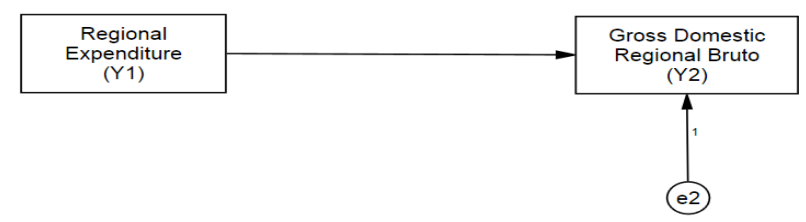

Picture 5. The direct effect of Regional Expenditure on Gross Regional Domestic Products

Determine Direct Effect of Regional Own Revenue, General Allocation Fund, Revenue Sharing Fund, and Regional Expenditure on Gross Regional Domestic Products

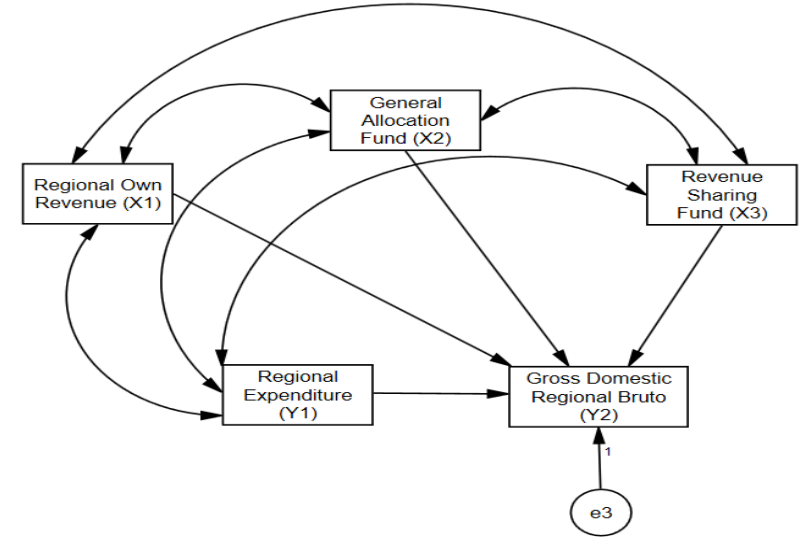

Picture 6. The Direct Effect of Regional Own Revenue, General Allocation Fund, Revenue Sharing Fund, and Regional Expenditure on Gross Regional Domestic Products mediated

Proof of the role mediation variable of Regional Expenditure in the effect of Regional Own Revenue, General Allocation Fund and Revenue Sharing Fund On Gross Regional Domestic Products is done by using criteria: If the significance of the direct Regional Own Revenue, General Allocation Fund and Revenue Sharing Fund and the direct influence of Regional Expenditure on Gross Regional Domestic Products is less than the alpha value (5\%) and regression coefficient at the point 1 is less than point 2 and the regional own revenue, general allocation fund, revenue sharing fund and regional expenditure on against gross regional domestic products (point 3) is not significant, then regional expenditure acts as mediation variable. To significantly test the regional mediation role using the Z-Sobel Test. The significant test steps for Z-Sobel Test are:

1) Determine the direct effect of Regional Own Revenue, General Allocation Fund and Revenue Sharing Fund on Regional Expenditure using SPSS 24.0.

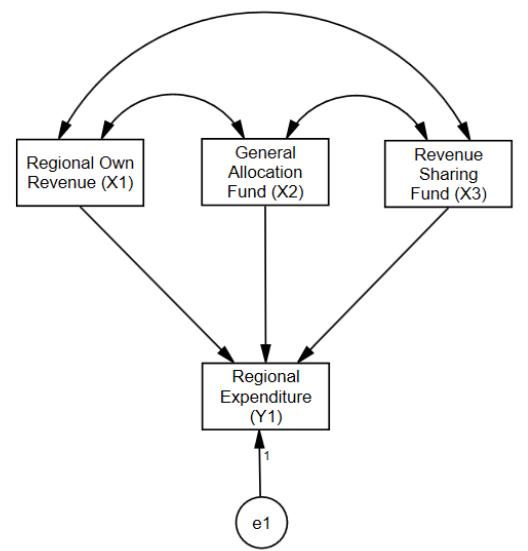

Picture 7. Effect of Regional Own Revenue, General Allocation Fund and Revenue Sharing Fund on Regional Expenditure 
2) Determine the direct effect of Regional Expenditure on Gross Regional Domestic Products using SPSS 24.0.

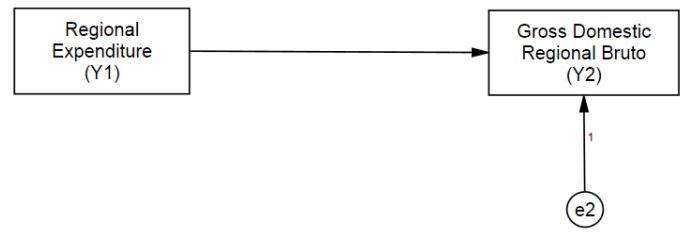

Picture 8. direct effect of Regional Expenditure on Gross Regional Domestic Products

3) Calculate value of Z-Sobel direct effect of Regional Own Revenue, General Allocation Fund Revenue Sharing Fund on Gross Regional Domestic Products mediated Regional Expenditure with Sobel Calculator. The test steps of indirect influence of mediation are:

a) Determine Z-value mediating effect Regional Expenditure in Regional Own Revenue effect on Gross Regional Domestic Products.

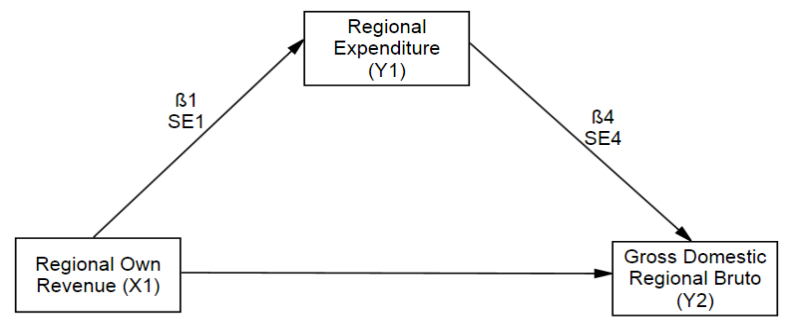

Picture 9. mediating effect Regional Expenditure in Regional Own Revenue effect on Gross Regional Domestic Products

b) Determine Z-value mediating effect Regional Expenditure In Influence General Allocation Fund on Gross Regional Domestic Products

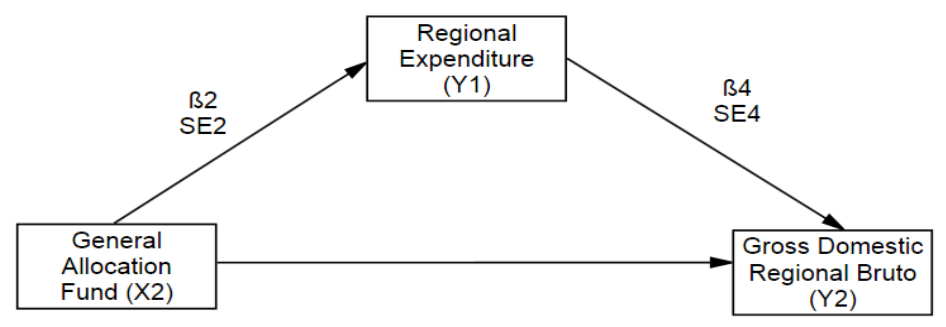

Picture 10. mediating effect Regional Expenditure In Influence General Allocation Fund on Gross Regional Domestic Products

c) Determine Z-value mediating effect Regional Expenditure in Revenue Sharing Fund effect on Gross Regional Domestic Products.

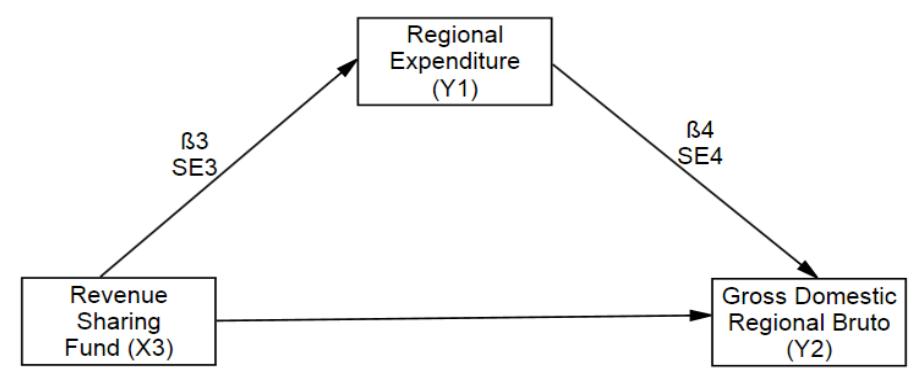

Picture 11. mediating effect Regional Expenditure in Revenue Sharing Fund effect on Gross Regional Domestic Products 
4) Compare p-value of Z-Sobel test with alpha value (5\%) to determinate significant mediating effect by Regional Expenditure in the influence of Regional Own Revenue, General Allocation Fund, Revenue Sharing Fund on Gross Regional Domestic Products. If p-value Z-Sobel $\leq$ alpha value (5\%), then has significant of mediating effect by Regional Expenditure.

\section{Result and Discussion}

Here outlined the research results and discussion over research results. If necessary can use sub headings-like format that has been elaborated above. If you need to use the table or figure and then are required to use the table format and images as has been outlined above. To prove the hypothesis that has been formulated, the data analysis strategy in this study consists of three stages.

Test the influence of the dominant factors that influence Regional Expenditure using regression analysis with AMOS 18.0 program.

Based on the output of AMOS program 18.0, it is known the estimated value of regression coefficients, t-statistics and p-values as shown in Table 1. Table 1, shows that the t-statistics of Regional Own Revenue, General Allocation Fund and Revenue Sharing Fund values are 12.25, 1.03 and 2.02. Based on the criteria for t-statistics, the General Allocation Fund variable has the most dominant influence on Regional Expenditure, then Sharing Fund Revenues and Regional Own Revenue.

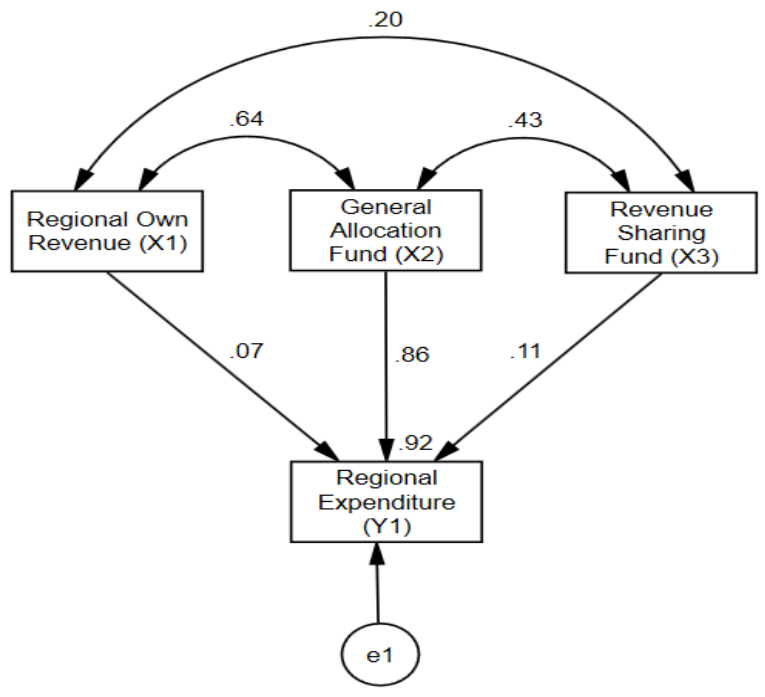

Picture 12. Direct Effects of Regional Own Revenue, General Allocation Fund and Revenue Sharing Fund on Regional Expenditure

Table 1. Output Effect of Regional Own Revenue, General Allocation Fund and Revenue Sharing Fund on Regional Expenditure

\begin{tabular}{|c|c|c|c|c|c|c|}
\hline \multicolumn{3}{|c|}{ Variable of Influence } & \multirow{2}{*}{$\begin{array}{l}\text { Estimate } \\
2.16\end{array}$} & \multirow{2}{*}{$\frac{\text { Standard Error (SE) }}{0.18}$} & \multirow{2}{*}{$\begin{array}{c}\text { T-Statistics } \\
12.25\end{array}$} & \multirow{2}{*}{$\begin{array}{c}\text { P-Value } \\
* * *\end{array}$} \\
\hline Y1 & $<---$ & $\mathrm{X} 2$ & & & & \\
\hline Y1 & $\begin{array}{l}<-- \\
\end{array}$ & $\mathrm{X} 1$ & 0.29 & 0.28 & 1.03 & 0.30 \\
\hline Y1 & $\begin{array}{l}<-- \\
\end{array}$ & X3 & 1.49 & 0.74 & 2.02 & 0.04 \\
\hline \multicolumn{7}{|l|}{ Notes: } \\
\hline \multicolumn{3}{|c|}{$\begin{array}{l}\mathrm{Y} 1=\text { Regional Expenditure } \\
\mathrm{X} 1=\text { Regional Own Revenue } \\
\mathrm{X} 2=\text { General Allocation Fund } \\
\mathrm{X} 3=\text { Revenue Sharing Fund }\end{array}$} & & & \multicolumn{2}{|c|}{$* * * \leq$ alpha $1 \%$} \\
\hline
\end{tabular}

Test the influence of direct and indirect effects of Regional Own Revenue, General Allocation Fund and Revenue Sharing Fund on Regional Expenditure and Gross Regional Domestic Products using path analysis with AMOS 18.0 program

Based on the output of AMOS program 18.0, it is known the direct and indirect effect of Regional Own Revenue, General Allocation Fund and Revenue Sharing Fund on Regional Expenditure and Gross 
Regional Domestic Products as shown in Table 2. Based on Picture 8 and Table 2, the hypothesis 1, 2 and 3 are tested using the t-test criteria by comparing the p-value with the value $\alpha(5 \%)$.

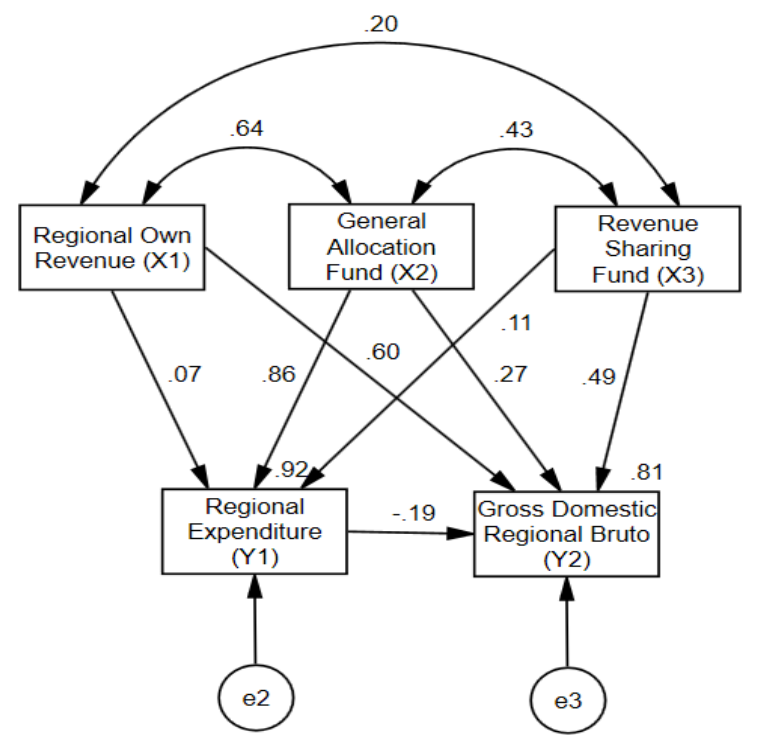

Picture 13. Direct and indirect effects of Regional Own Revenue, General Allocation Fund and Revenue Sharing Fund on Regional Expenditure and Gross Regional Domestic Products

Table 2. Direct, Estimate, T-Statistics, P-value, Indirect and Total Effect

\begin{tabular}{|c|c|c|c|c|c|c|c|c|}
\hline \multicolumn{3}{|c|}{ Variable Influence } & \multicolumn{3}{|c|}{$\mathrm{T}-$} & \multirow{2}{*}{$\begin{array}{l}\text { Direct } \\
\text { Effect }\end{array}$} & \multirow{2}{*}{$\begin{array}{c}\begin{array}{c}\text { Indirect } \\
\text { Effect }\end{array} \\
0.000\end{array}$} & \multirow{2}{*}{$\begin{array}{c}\begin{array}{c}\text { Total } \\
\text { Effect }\end{array} \\
0.067\end{array}$} \\
\hline Y1 & $<---$ & $\mathrm{X} 1$ & 0.286 & 1.031 & 0.302 & & & \\
\hline Y1 & $<---$ & $\mathrm{X} 2$ & 2.159 & 12.251 & $* * *$ & 0.862 & 0.000 & 0.862 \\
\hline Y1 & <--- & X3 & 1.495 & 2.022 & 0.043 & 0.112 & 0.000 & 0.112 \\
\hline $\mathrm{Y} 2$ & $<---$ & $\mathrm{X} 1$ & 34.913 & 5.981 & $* * *$ & 0.602 & -0.013 & 0.589 \\
\hline $\mathrm{Y} 2$ & <--- & $\mathrm{X} 2$ & 9.072 & 1.054 & 0.292 & 0.268 & -0.165 & 0.103 \\
\hline $\mathrm{Y} 2$ & $\begin{array}{ll}<-- \\
\end{array}$ & $\mathrm{X} 3$ & 89.113 & 5.482 & $* * *$ & 0.493 & -0.021 & 0.472 \\
\hline $\mathrm{Y} 2$ & $<---$ & Y1 & -2.595 & -0.719 & 0.472 & -0.192 & 0.000 & -0.192 \\
\hline $\begin{array}{l}\text { Notes: } \\
\mathrm{Y} 2= \\
\mathrm{Y} 1= \\
\mathrm{X} 1= \\
\mathrm{X} 2= \\
\mathrm{X} 3=\end{array}$ & $\begin{array}{l}\text { ross } R \\
\text { egion } \\
\text { egion } \\
\text { enera } \\
\text { evenu }\end{array}$ & $\begin{array}{l}\text { gion } \\
\text { Exp } \\
\text { Owı } \\
\text { Alloc } \\
\text { Sha }\end{array}$ & $\begin{array}{l}\text { Domestic } \\
\text { nditure } \\
\text { Revenue } \\
\text { tion Fund } \\
\text { ng Fund }\end{array}$ & oducts & & & $* * * \leq$ & a $1 \%$ \\
\hline
\end{tabular}

Test the influence of Regional Own Revenue, General Allocation Fund and Revenue Sharing Fund on Regional Expenditure (Hypothesis 1). The influence Test of Regional Own Revenue, General Allocation Fund and Revenue Sharing Fund on Regional Expenditure is done by comparing p-value with 0.05. if pvalue $\leq 0.05$ there is a significant influence of independent variables on dependent variables. Table 2 , it is known that the independent variable that has p-value $>0.05$ is the variable regional own revenue $(0.302)$ while the General Allocation Fund $(* * *=<0.01)$ and Revenue Sharing Fund $(0.043)$ variable has a pvalue $\leq 0.05$. Thus it can be concluded that at a 95\% confidence level General Allocation Fund and Revenue Sharing Fund can be stated to have a significant effect on the Regional Expenditure of regency / municipality in Southeast Sulawesi in 2016-2017. The results of this study support the research (Armawaddin, 2015); (Armawaddin, Rumbia, \& Afiat, 2018); (Afrizawati, 2015); (Devita, Delis, \& Junaidi, 2014); (Ernayani, 2017); (Sari \& Asyik, 2017); (Putra \& Dwirandra, 2015); (Solikin, 2016); (Inayati \& Setiawan, 2017); (Masayu Rahma Wati, 2017); (Murniasih \& Mulyadi, 2011); (Nurdini, Wiratno, \& Farida, 2015) found regional own revenue variables, general allocation of funds and revenue sharing fund have significant influence on regional expenditure, but not support the research (Herlina, 2013); (Tahar \& Zakhiya, 2011) found general allocation of fund have not significant influence on regional expenditure. 
On the other hand, Regional Own Revenue has no significant effect on the Regional Expenditure of regency / municipality in Southeast Sulawesi in 2016-2017. The results of this study support the research (Herlina, 2013); (Tahar \& Zakhiya, 2011) but not support the research (Armawaddin, 2015); (Armawaddin, Rumbia, \& Afiat, 2018); (Afrizawati, 2015); (Devita, Delis, \& Junaidi, 2014); (Ernayani, 2017); (Sari \& Asyik, 2017); (Putra \& Dwirandra, 2015); (Solikin, 2016); (Inayati \& Setiawan, 2017); (Masayu Rahma Wati, 2017); (Murniasih \& Mulyadi, 2011); (Nurdini, Wiratno, \& Farida, 2015) found regional own revenue fund have significant influence on regional expenditure not support the research.

Test the influence of Regional Own Revenue, General Allocation Fund and Revenue Sharing Fund on Gross Regional Domestic Products (Hypothesis 2).The influence Test of Regional Own Revenue, General Allocation Fund and Revenue Sharing Fund on Gross Regional Domestic Products is comparing $\mathrm{p}$-value with 0.05 . if $\mathrm{p}$-value $\leq 0.05$ there is a significant influence of independent variables on dependent variables. Table 2, it is known that the independent variable that has p-value $<0.05$ is the variable Revenue Sharing Fund $(* * *=<<0.01)$ and Regional Own Revenue $(* * *=<<0.01)$ while the General Allocation Fund (0.292) variable has a p-value $>0.05$. Thus it can be concluded that at a $95 \%$ confidence level Revenue Sharing Fund and Regional Own Revenue can be stated to have a significant effect on the Gross Regional Domestic Products of regency / municipality in Southeast Sulawesi in 2016-2017.

The results of this study support the research (Nasution, 2009); (Rarung, 2016); (Setiyawati, 2007); (Uhise, 2012); found regional own revenue and revenue sharing fund have significant influence on gross regional domestic products, but not support the research (Herlina, 2013); (Tahar \& Zakhiya, 2011) found General Allocation Fund have not significant influence on Gross Regional Domestic Products not support the research. On the other hand, General Allocation Fund has no significant effect on the Gross Regional Domestic Products of regency / municipality in Southeast Sulawesi in 2016-2017. The results of this study support the research (Herlina, 2013); (Tahar \& Zakhiya, 2011) found General Allocation Fund have not significant influence on Gross Regional Domestic Products, but not support the research (Nasution, 2009); (Rarung, 2016); (Setiyawati, 2007); (Uhise, 2012); found regional General Allocation Fund have significant influence on Gross Regional Domestic Products (Nasution, 2009); (Rarung, 2016); (Setiyawati, 2007); (Uhise, 2012); found General Allocation Fund have significant influence on Gross Regional Domestic Products.

Test the influence of Regional Expenditure on Gross Regional Domestic Products (Hypothesis 3) The influence Test of Regional Expenditure on Gross Regional Domestic Products is comparing p-value with 0.05 . if $\mathrm{p}$-value $\leq 0.05$ there is a significant influence of independent variables on dependent variables. Table 2, it is known that the Regional Expenditure (0.472) that has p-value $>0.05$. Thus it can be concluded that at a 95\% confidence level Regional Expenditure, has no significant effect on the Gross Regional Domestic Products of regency / municipality in Southeast Sulawesi in 2016-2017. The results of this study support the research but not support the research.

The results of this study support the research (Herlina, 2013) Regional Expenditure have not significant influence on Gross Regional Domestic Products, but not support the research (Deviani, 2016); (Deswantoro, 2017) found Regional Expenditure have significant influence on Gross Regional Domestic Products.

Test the mediation effect of Regional Expenditure in the influence of Regional Own Revenue, General Allocation Fund and Revenue Sharing Fund on Gross Regional Domestic Products (Hypothesis 4).

Significant test of mediation effect by comparing the direct effect of Regional Own Revenue, General Allocation Fund and Revenue Sharing Fund to Regional Expenditure with the influence of Regional Own Revenue, General Allocation Fund and Revenue to Gross Regional Domestic Products.

Based on Picture 9, it is known that the value of Z-Sobel Statistics is 1,072 with a two-tailed p-value of 0.40406068 and this value is greater than the alpha value of $5 \%(0.05)$. Thus it can be concluded that there is no significant regional mediation role under the influence of the Regional Own Revenue on Gross Regional Domestic Products. Based on Picture 10, it is known that the value of Z-Sobel Statistics is 1,072 with a two-tailed p-value of 0.00000011 and this value is smaller than the alpha value of 5\% (0.05). Thus it can be concluded that there is a significant mediation effect of Regional Expenditure under the influence of the General Allocation Fund on Gross Regional Domestic Products. Based on Picture 11, it is known that the value of Z-Sobel Statistics is 1,072 with a two-tailed p-value of 0.0396320 and this value is smaller than the alpha value of 5\% (0.05). Thus it can be concluded that there is a significant influence of Regional Expenditure mediation in the Sharing Fund Fund's influence on Gross Regional Domestic Products. 


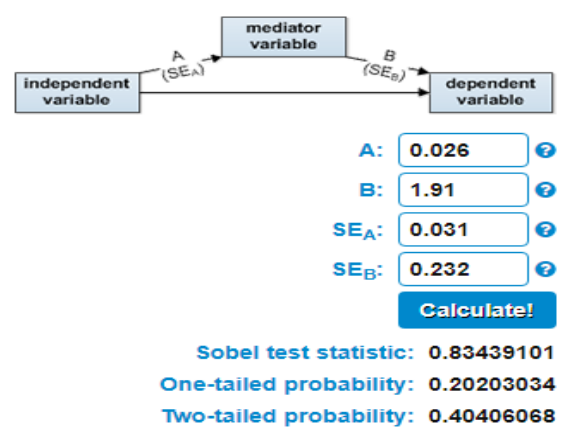

Picture 14. Effect of Regional Own Revenue on Gross Regional Domestic Products Mediated by Regional Expenditure

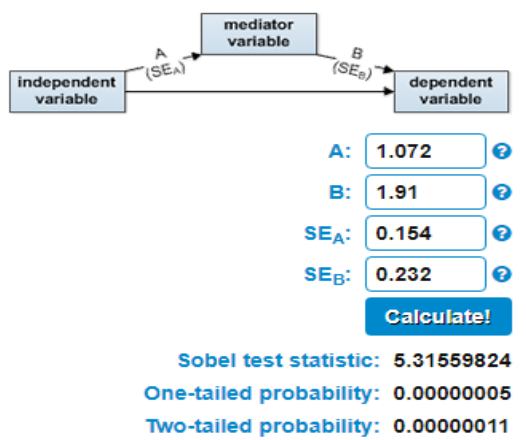

Picture 15. Effect of General Allocation Fund on Gross Regional Domestic Products mediated by Regional Expenditure

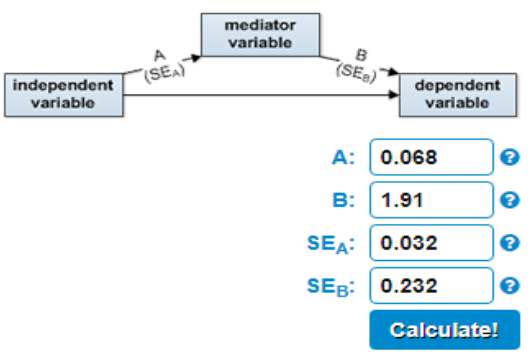

Sobel test statistic: 2.05756409

One-tailed probability: 0.0198160

Two-tailed probability: 0.0396320

Picture 16. Effect Revenue Sharing Fund on Gross Regional Domestic Products mediated by Regional Expenditure

Based on the results of the direct effect test concluded that General Allocation Fund and Revenue Sharing Fund had significant influence on Regional Expenditure. Regional Own Revenue and Revenue Sharing Fund had significant influence on Gross Regional Domestic Products. But Regional Own Revenue hadn't significant influence on the Regional Expenditure and General Allocation Fund hadn't significant influence on Gross Regional Domestic Products. The insignificant effect of Regional Own Revenue on Regional Expenditure is because, based on Regional Own Revenue data, there is a high gap from Regency / Municipality in Southeast Sulawesi as shown in Figure below. 


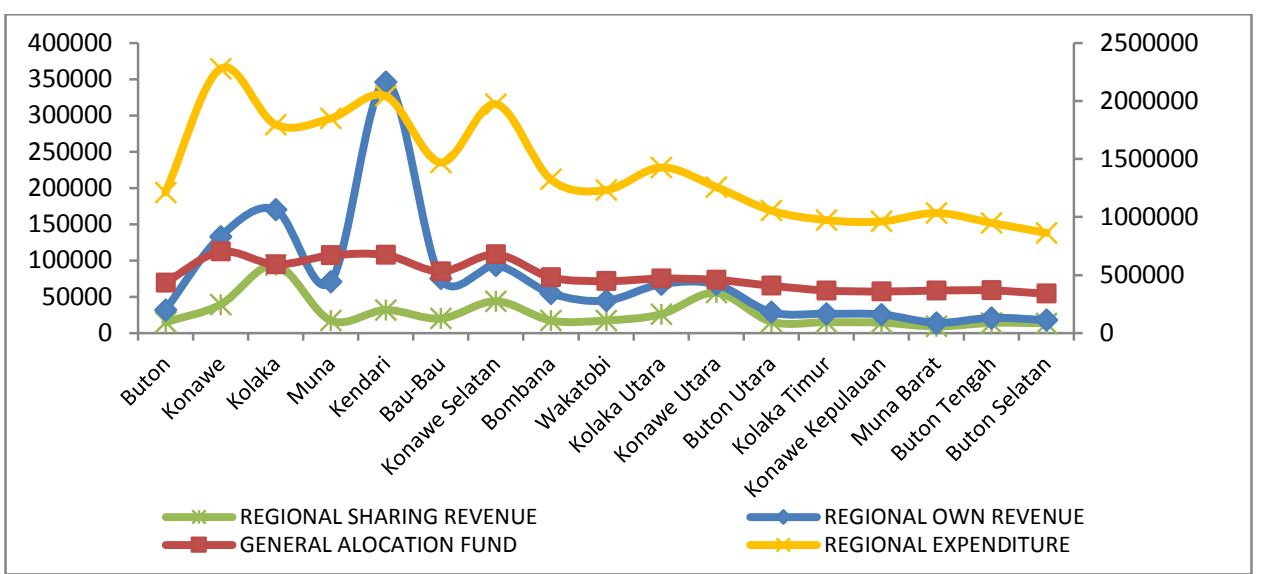

Picture 17. Relationship Regional Own Revenue, General Allocation Fund and Revenue Sharing Fund with Regional Expenditure

Picture 17, showing that the Regional Own Revenue of Kendari City shows the highest extreme value compared to other Regency / Municipality in Southeast Sulawesi in 2016-2017. This value is not in line with the Regional Expenditure's average value in the same period so that this is likely to cause the insignificant influence of Regional Own Revenue on Regional Expenditure. The insignificant influence of the General Allocation Fund on Gross Regional Domestic Products is due to a high gap in the number of General Allocation Funds from Regency / Municipality in Southeast Sulawesi as shown in the Figure below.

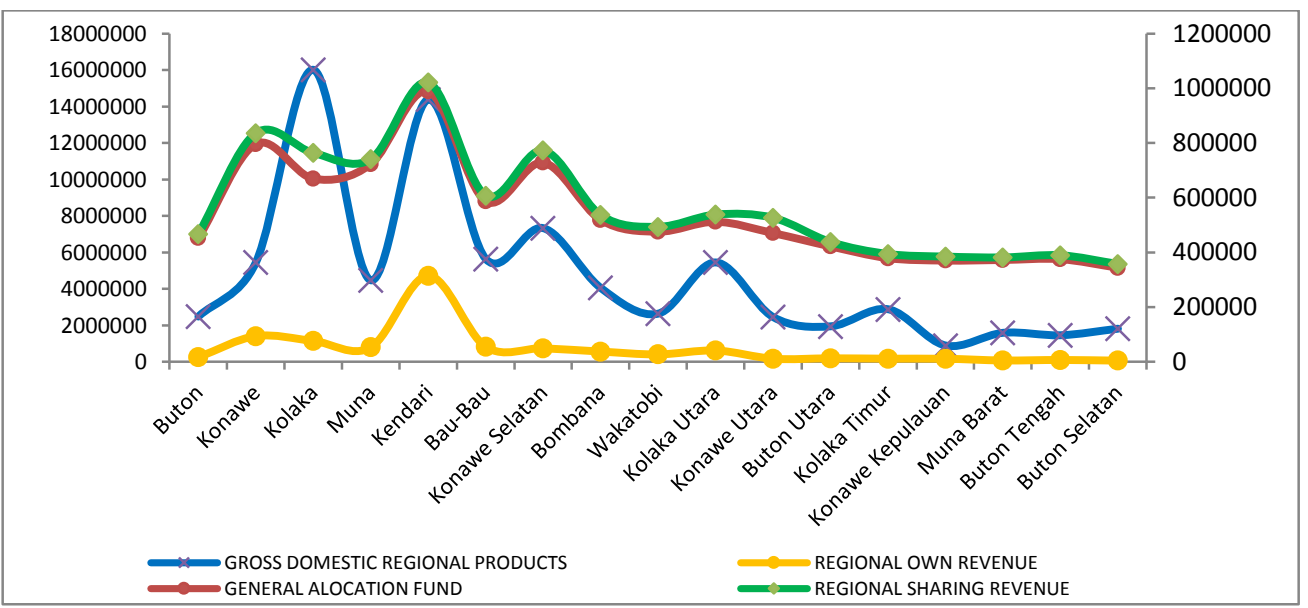

Picture 18. Relationship Regional Own Revenue, General Allocation Fund and Revenue Sharing Fund with Gross Regional Domestic Products

Picture 18, data fluctuations of the General Allocation Fund have a pattern that is not in line with Gross Regional Domestic Products data, when the General Allocation Fund value decreases, so Gross Regional Domestic Products shows a rise. This pattern is repeated several times and is different from the Regional Own Revenue and Regional Sharing Fund data, so this is likely to cause the insignificant influence of the General Allocation Fund on Regional Domestic Products.

The results of the test of indirect influence / mediation influence concluded that the Regional Expenditure plays role in the mediating significant influence of the Revenue Sharing Fund and General Allocation Fund on Gross Regional Domestic Products. The Regional Expenditure, on the other hand, plays a role in mediating insignificantly in the Regional Own Revenue on Gross Regional Domestic Products.

\section{Conclusions, suggestions and limitations}

Based on the results of research and discussion, it can be concluded that: (1) General Allocation Funds are the dominant factors affecting Regency / Municipality Regional Expenditure in Southeast Sulawesi in 2016-2017. (1) General Allocation Funds and Revenue Sharing Funds significantly affect 
Regional Expenditures, while Regional Own Revenues are insignificant. (2) Regional Own Revenue and Revenue Sharing Fund significantly affect the Gross Regional Domestic Product, while the General Allocation Fund is not significant. (3) Regional Expenditure significantly mediated the effect of General Allocation Funds and Revenue Sharing Fund on Gross Regional Domestic Products, while Regional Expenditures do not significantly mediate in the influence of Regional Own Revenue on Gross Regional Domestic Product.

Analysis of the effect of Regional Own Revenue and Revenue Sharing Fund in this study is able to predict General Allocation Fund. While the Regional Expenditure allocation to predicting Gross Regional Domestic Product in reality is sourced from the General Allocation Fund. Therefore, the next researcher should formulate an appropriate estimation model so that all influences between variables in the regression equation produce a significant effect. The limitation of this study is that the observation period is still short (only two years) due to the new blooms of several Regency / Municipality in Southeast Sulawesi or other object. Therefore, it is expected to increase the observation period and formulate an appropriate model of the five variables in this study in the future.

\section{References}

Afrizawati. (2015). Analisis Flypaper Effect Pada Belanja Daerah Kabupaten dan Kota Di Provinsi Banten. In Jurnal (Vol. 11, pp. 15-25).

Armawaddin, M. (2015). Analisis Flypapper Effect Pada Belanja Daerah Kabupaten/Kota di Sulawesi Tenggara. Jurnal Ekonomi Pembangunan, XVI, 13-19.

Armawaddin, M., Rumbia, W. A., \& Afiat, M. N. (2018). Analisis Flypaper Effect Belanja Daerah Kabupaten / Kota di Sulawesi. Jurnal Ekonomi Dan Pembangunan Indonesia, 18(1), 77-91.

Deswantoro, D. B. (2017). Pengaruh Belanja Daerah Berdasarkan Klasifikasi Ekonomi terhadap Pertumbuhan Ekonomi dan Kesejahteraan Masyarakat di Kabupaten / Kota Provinsi Kalimantan Barat Tahun 2010 - 2015. Jurnal Ekonomi Bisnis Dan Kewirausahaan, 6(3), 187-210.

Deviani. (2016). Analisis belanja daerah terhadap pertumbuhan ekonomi dan pendidikan (Studi Empiris Kota dan Kabupaten di Sumatera Barat). Pekbis Jurnal, 8(1), 1-13.

Devita, A., Delis, A., \& Junaidi. (2014). Pengaruh Pendapatan Asli Daerah, Dana Alokasi Umum dan Jumlah Penduduk terhadap Belanja Daerah Kabupaten/Kota di Provinsi Jambi. Jurnal Perspektif Pembiayaan Dan Pembangunan Daerah, 2(2), 63-70.

Ernayani, R. (2017). Pengaruh Pendapatan Asli Daerah , Dana Alokasi Umum , Dana Alokasi Khusus dan Dana Bagi Hasil terhadap Belanja Daerah ( Studi Kasus pada 14 Kabupaten / Kota di Provinsi Kalimantan Timur Periode 2009-2013 ) Undang-Undang Asli Daerah ( PAD ) Provinsi Kalima. Jurnal Sosial Humaniora Dan Pendidikan, 1(1), 43-52.

Herlina, E. (2013). Faktor-Faktor yang Mempengaruhi Belanja Daerah serta Dampaknya terhadap Produk Domestik Regional Bruto Kabupaten Berau. Ekonomika-Bisnis, 4(1), 25-44.

Inayati, N. I., \& Setiawan, D. (2017). Fenomena Plypaper Efect Pada Belanja Daerah Kabupaten/Kota Di Indonesia. EKUITAS (Jurnal Ekonomi dan Keuangan), 1(2), 220. https://doi.org/10.24034/j25485024.y2017.v1.i2.2062

Masayu Rahma Wati, C. M. F. (2017). Pengaruh Pendapatan Asli Daerah dan Dana Perimbangan Terhadap Belanja Daerah Kota Bandung. Jurnal Kajian Akuntansi, 1(1), 63-76.

Murniasih, E., \& Mulyadi, M. S. (2011). Pengaruh Transfer Pemerintah Pusat terhadap Perilaku Fiskal Pemerintah Daerah di Provinsi Kalimantan Timur. Jurnal Ekonomi Dan Pembangunan Indonesia, 12(1), 56-71.

Nasution, H. S. (2009). Analisis Faktor - Faktor yang Mempengaruhi Pertumbuhan Produk Domestik Regional Bruto Era Desentralisasi Fiskal Di Propinsi Banten Periode 2001 : 1-2009: 4. Media Ekonomi, 18(2), 29-48.

Nurdini, R., Wiratno, A., \& Farida, Y. N. (2015). Analisis Flypaper Effect Pada Dana Alokasi Umum (DAU), Dana Alokasi Khusus (DAK), Dana Bagi Hasil (DBH), Dan Pendapatan Asli Daerah (PAD) Terhadap Belanja Daerah (BD) Kabupaten/Kota Di Jawa Barat. Jurnal Akuntansi Dan Keuangan (JAKA), 2(1), 80-94.

Putra, I. B. D., \& Dwirandra, A. A. N. B. (2015). Dana Alokasi Umum, Dana Bagi Hasil, Dana Alokasi Khusus Dan Pendapatan Asli Daerah Provinsi Bali. Akuntansi Universitas Udayana, 13, 811-827.

Rarung, P. (2016). Pengaruh PAD Dan DAU Terhadap Pdrb Di Kota Manado. Jurnal Berkala Ilmiah Efisiensi, 16(3), 449-460.

Sari, E. T. I., \& Asyik, N. F. (2017). Pengaruh PAD, DAU, DAK dan DBH Terhadap Belanja Daerah ( Studi Pada Pemerintah Daerah Kabupaten / Kota Di Provinsi Jawa Timur). Jurnal Ilmu Dan Riset Akuntansi, 6(22). 
Setiyawati, A. (2007). Analisis Pengaruh PAD, DAU, DAK dan Belanja Pembangunan Terhadap Pertumbuhan Ekonomi , Kemiskinan dan Pengangguran Pendekatan Analisis Jalur. Jurnal Akuntansi Dan Keuangan Indonesia, 4(2), 211-228. https://doi.org/10.21002/jaki.2007.11

Solikin, A. (2016). Analisis Flypaper Effect Pada Pengujian Pengaruh Dana Alokasi Umum (DAU), Pendapatan Asli Daerah (PAD), dan Sisa Lebih Penghitungan Anggaran (Silpa) Terhadap Belanja Pemerintah Daerah Di Indonesia. Jurnal Akuntansi Dan Bisnis, 16(1), 11-25.

Tahar, A., \& Zakhiya, M. (2011). Pengaruh Pendapatan Asli Daerah dan Dana Alokasi Umum Terhadap Kemandirian Daerah Dan Pertumbuhan Ekonomi Daerah. Jurnal Akuntansi Dan Investasi, 12(1), 8899.

Uhise, S. (2012). Dana Alokasi Umum (DAU) Pengaruhnya Terhadap Pertumbuhan Ekonomi Sulawesi Utara Dengan Belanja Modal Sebagai Variabel Intervening. Jurnal EMBA, 1(4), 1677-1686. Retrieved from https://ejournal.unsrat.ac.id/index.php/emba/article/view/3347 
Testing Effect Mediation of Regional Expenditure ... (Armawaddin, Nur) 